\title{
Boiling effects on trace metal(loid)s and sulfur isotopes in shallow- submarine base metal sulfides, Milos Island, Greece
}

\author{
ANNA SCHAARSCHMIDT ${ }^{1}$, KARSTEN M. HAASE ${ }^{1}$, \\ REINER KLEMD ${ }^{1}$, MANUEL KEITH ${ }^{1}$, PANAGIOTIS C. \\ VOUDOURIS $^{2}$, DIMITRIOS ALFIERIS ${ }^{3}$ AND MICHAEL \\ WIEDENBECK $^{4}$ \\ ${ }^{1}$ GeoZentrum Nordbayern, Friedrich-Alexander-Universität \\ (FAU) Erlangen-Nürnberg \\ ${ }^{2}$ Department of Mineralogy-Petrology, University of Athens \\ ${ }^{3}$ Kairi Str. 6 \\ ${ }^{4}$ GFZ German Research Centre for Geosciences \\ Presenting Author: anna.schaarschmidt@fau.de
}

Boiling is a common process in porphyry-epithermal and shallow-marine hydrothermal systems, playing a key role in the enrichment and precipitation of precious and critical metal(loid)s. Recent studies suggest that the distribution of trace elements in pyrite may help to identify boiling zones in hydrothermal systems [1]. New trace element (LA-ICPMS) and in-situ sulfur isotope data (SIMS) on epithermal pyrite from the shallow-submarine vein mineralization at Milos Island in the Aegean volcanic arc indicate that 'boiled fluids' precipitate pyrite with low As/Sb, high $\mathrm{Tl} / \mathrm{Cu}$, and negative $\delta^{34} \mathrm{~S}_{\mathrm{VCDT}}$ values (to $-6 \%$ ). Redox reactions at a deeper boiling horizon led to $\delta^{34} \mathrm{~S}_{\mathrm{H} 2 \mathrm{~S}}$ shift towards negative values and the removal of As, Ag, $\mathrm{Cu}, \mathrm{Pb}$, and $\mathrm{Co}$ from these fluids. Sampling of vein-type sulfides from different depth levels at NW Milos provides insights into the vertical distribution of metal(loid)s in the subseafloor, as indicated by upwards increasing $\mathrm{Pb}, \mathrm{Ag}$, and $\mathrm{Sb}$ concentrations in sulfides together with a significant $\mathrm{Ag}$ enrichment in the upper section of the boiling zone at relatively low fluid temperatures of $<200^{\circ} \mathrm{C}$. By contrast, high concentrations of $\mathrm{Hg}, \mathrm{Tl}, \mathrm{Bi}$, and $\mathrm{Mo}$ are observed in sulfides from the shallowest part of the hydrothermal system, where acidic fluids form by condensation of vapor into circulating seawater in the subseafloor. This is in accordance with the enrichment of these elements in seafloor sulfides from active submarine vents at Paleochori Bay, nearshore Milos Island [2]. We conclude that boiling and mixing with seawater controls the distribution of base and precious metal(loid)s in the subseafloor of shallow-submarine hydrothermal systems and may suppress the formation of massive sulfides at the seafloor.

[1] Román et al. (2007), Geochimica et Cosmochimica Acta 246, 60-85.

[2] Voudouris et al. (2021), Minerals 11:1, 14. 